Н.Н. Покровский

Досуговые и образовательные практики новосибирских коллекционеров транспортной техники периода Великой Отечественной войны

DOI: 10.31518/2618-9100-2020-3-15

УДК 394(47)

Выходные данные для цитирования:

Покровский Н.Н. Досуговые и образовательные практики новосибирских коллекционеров транспортной техники периода Великой Отечественной войны // Исторический курьер. 2020.№ 3 (11). C. 152-161. URL: http://istkurier.ru/ data/2020/ISTKURIER-2020-3-15.pdf
N.N. Pokrovsky*

\section{Leisure and Educational Practices of Novosibirsk Collectors of Transport Equipment During the Great Patriotic War}

DOI: 10.31518/2618-9100-2020-3-15

How to cite:

Pokrovsky N.N. Leisure and Educational Practices of Novosibirsk Collectors of Transport Equipment During the Great Patriotic War // Historical Courier, 2020, No. 3 (11), pp. 152-161. [Available online:] http://istkurier.ru/data/2020/ISTKURIER-2020-315.pdf

Abstract. The public interest in technology during the Great Patriotic War has steadily increased over time. Based on historical monuments in private collections of Novosibirsk collectors, the article provides an overview of some types of transport equipment of this period; describes a number of their leisure and educational practices. This publication opens a series with the aim of introducing into the scientific circulation new sources on the history of social formations of lovers of ancient motor vehicles of Novosibirsk and the Novosibirsk Region. The objects of research include the selected items from private collections of retro technical equipment. The subject is leisure and educational practices of Novosibirsk collectors of motor vehicles. The methodological basis of the work is made up of the basic principles of modern historical science, as well as the method of synthesis of historical and technical study of an object. The scientific novelty of the work is related to the introduction into the scientific circulation of previously unpublished items from these collections. The article covers the period from the beginning of the 1930s to the end of the 1940s. Such a time frame is determined by the period of the Great Patriotic War along with the years preceding it in the formation of the domestic auto industry. The upper time line is marked by the beginning of a new post-war era. At this time, the old models of technology began to be replaced with the new, modern models. An approach and production ideology of the strategic direction of the domestic auto industry also changed.

Keywords: history of technology; museology; oldtimers; technical heritage; socio-cultural space.

The article has been received by the editor on 19.05.2020.

Full text of the article in Russian and references in English are available below.

Аннотация. Интерес общества к технике периода Великой Отечественной войны с течением времени не только не снижается, но, напротив, неизменно возрастает. В статье делается обзор некоторых видов автомототехники, выпускающейся с начала 1930-х по конец 1940-х гг. Данные временные рамки определяются самим периодом Великой Отечественной войны с предшествующими ей годами становления отечественной автоиндустрии. Верхняя временная граница обозначена началом новой послевоенной эпохи, когда на смену прежним моделям техники стали приходить новые, современные образцы, изменились подход и производственная идеология стратегического направления отечественной

\footnotetext{
* Покровский Николай Николаевич, кандидат исторических наук, Институт истории Сибирского отделения Российской академии наук, Новосибирск, Россия, e-mail: pokrov@li.ru

Pokrovsky Nikolay N., Candidate of Historical Sciences, Institute of History of the Siberian Branch of the Russian Academy of Sciences, Novosibirsk, Russia, e-mail: pokrov@li.ru
} 
автопромышленности. Предметом работ также являются досуговые и образовательные практики новосибирских коллекционеров автомототехники. Публикация открывает серию статей, направленных на введение в научный оборот вещевых и письменных исторических источников, актуализацию научно-технического наследия.

Ключевые слова: история техники; музееведение; ретротехника; техническое наследие; социокультурное пространство.

Среди новосибирских коллекционеров автомототехники выделяется группа энтузиастов, увлекающихся поиском, реставрацией, изучением и представлением широкой общественности транспортной техники периода Великой Отечественной войны. Большинство из них объединены в клубы по интересам. Существуют общественные объединения, как чисто технического, так и комплексного типов. В последнем случае любители данного вида деятельности занимаются не только, а порой и не столько техникой, сколько военно-исторической реконструкцией. В подавляющем большинстве случаев речь идет о реконструкции событий периода Великой Отечественной войны. Нередко такие действия не обходятся без военной техники. В ряде случаев реконструкторы привлекают к участию в своих мероприятиях «чистых» коллекционеров техники, т.к. техника не является основным направлением их интересов и, вследствие чего, они испытывают существенный номенклатурный и количественный недостаток последней. В данной статье мы сосредоточимся на описании практик исключительно коллекционеров и реставраторов.

K началу Великой Отечественной войны Советский Союз переживал период становления собственной автомобильной промышленности. Ярославский автомобильный завод (ЯАЗ), организованный на базе национализированного завода промышленника В.А. Лебедева, в небольших количествах выпускал автобусы, троллейбусы и большегрузные автомобили серии Я, ЯГ, ЯС, являвшиеся модернизированным вариантом американского грузовика Уайт (White). В годы войны завод выпускал гусеничные артиллерийские тягачи Я-11, Я-12, Я-13. В Москве 1-й государственный автомобильный завод имени И.В. Сталина (ЗИС) под маркой ЗИС-5 собирал, по закупленной в Америке технологии, грузовые автомобили Dispatch SA фирмы Autocar Company, а также, с использованием конструктивных решений автомобиля Бьюик (Buick 1932), - легковые автомобили представительского класса ЗИС $101^{1}$.

На Горьковском автомобильном заводе имени В.М. Молотова, на закупленном у фирмы Ford Motor Company оборудовании, под маркой ГАЗ-АА, ГАЗ-ММ и ГАЗ-М1 выпускались отечественные варианты американских грузовых и легковых автомобилей. Во время Великой Отечественной войны горьковчане освоили выпуск армейских внедорожников ГАЗ-64, ГАЗ-67 и ГАЗ-67Б².

На заводе КИМ (с 1930 по 1939 г.- Государственный автосборочный завод имени Коммунистического интернационала молодежи; с 1939 г. до окончания Великой Отечественной войны - Московский автомобильный завод имени КИМ) в предвоенные годы готовились к серийному выпуску малолитражек КИМ-10. К июню 1941 г. их количество не превышало нескольких сотен штук. С началом военных действий выпуск КИМ-10 прекратился ${ }^{3}$. Мотостроительная отрасль СССР была представлена еще меньшем ассортиментом. Нами перечислены только базовые модели. Существовало множество их модификаций, экспериментальной и малосерийной техники.

K категории транспортных средств, встречавшихся на территории нашей страны в период Великой Отечественной войны, можно отнести и некоторые зарубежные модели или их отечественные аналоги более поздних лет выпуска. Так, немецкие автомобили BMW-321 и BMW-340 (послевоенная модификация BMW-326) после окончания войны выпускались при участии СССР в городе Айзенах (Eisenach). Мотоциклы К-1Б «Киевлянин» и мотоколяски

\footnotetext{
${ }^{1}$ Технические характеристики автомобилей. М., 1958.

${ }^{2}$ Вассерман Г.М., Куняев Н.А. Автомобиль ГАЗ-67Б. М., 1949.

${ }^{3}$ За рулем. 1939. № 15. С. 9-11.
} 
К-1B «Киевлянин», выпускавшиеся в нашей стране с 1946 г., являлись отечественным вариантом довоенной немецкой машины Wanderer-1Sp, а малолитражки «Москвич-400» и «Москвич-401» завода МЗМА - модификацией довоенного Opel-K38.

С конца 1941 г. в СССР начали поступать транспортные средства от союзных государств по линии ленд-лиза. Это автомобили Studebaker US6, Willys MB, Ford GPV, Dodge WC-51, более известный как Dodge 3/4 и др. Номенклатура транспортной техники Рейха была представлена в более широком масштабе. Это и упомянутые уже легковые и грузовые «Опели», «БМВ», «Мерседесы», «Майбахи», «Манны», «Фольксвагены» и т.д.

Заметная часть ассортимента советской автотранспортной техники рассматриваемого периода имеется в собрании новосибирского коллекционера А. Гайдамаки. Аркадий Александрович Гайдамака родился в 1963 г. в Новосибирске. Окончил Новосибирский электротехнический институт связи по специальности инженер-разработчик систем связи. Первый опыт ремонта мототехники получил еще в школьные годы, помогая соседу восстанавливать мотороллеры советского производства. Увлеченность ретротехникой пришла к Аркадию Александровичу значительно позже. Первой самостоятельной работой в данном направлении явилась автомашина ГАЗ-67Б. Этот автомобиль образца 1944 г. он приобрел в 2004 г. Автомобиль ГАЗ-67Б был создан в военные годы коллективом ГАЗ, как развитие первых советских внедорожников ГАЗ-64 и ГАЗ-67. Полноприводные легковые автомобили ГАЗ-67Б с упрощенным открытым кузовом, имевшим вырезы вместо дверей, создан, как и его предшественники, под руководством ведущего конструктора ГАЗа В.А. Грачева на базе агрегатов горьковского ГАЗ-М1. Широко использовался как штабной и разведывательный автомобиль, а также как легкий артиллерийский тягач.

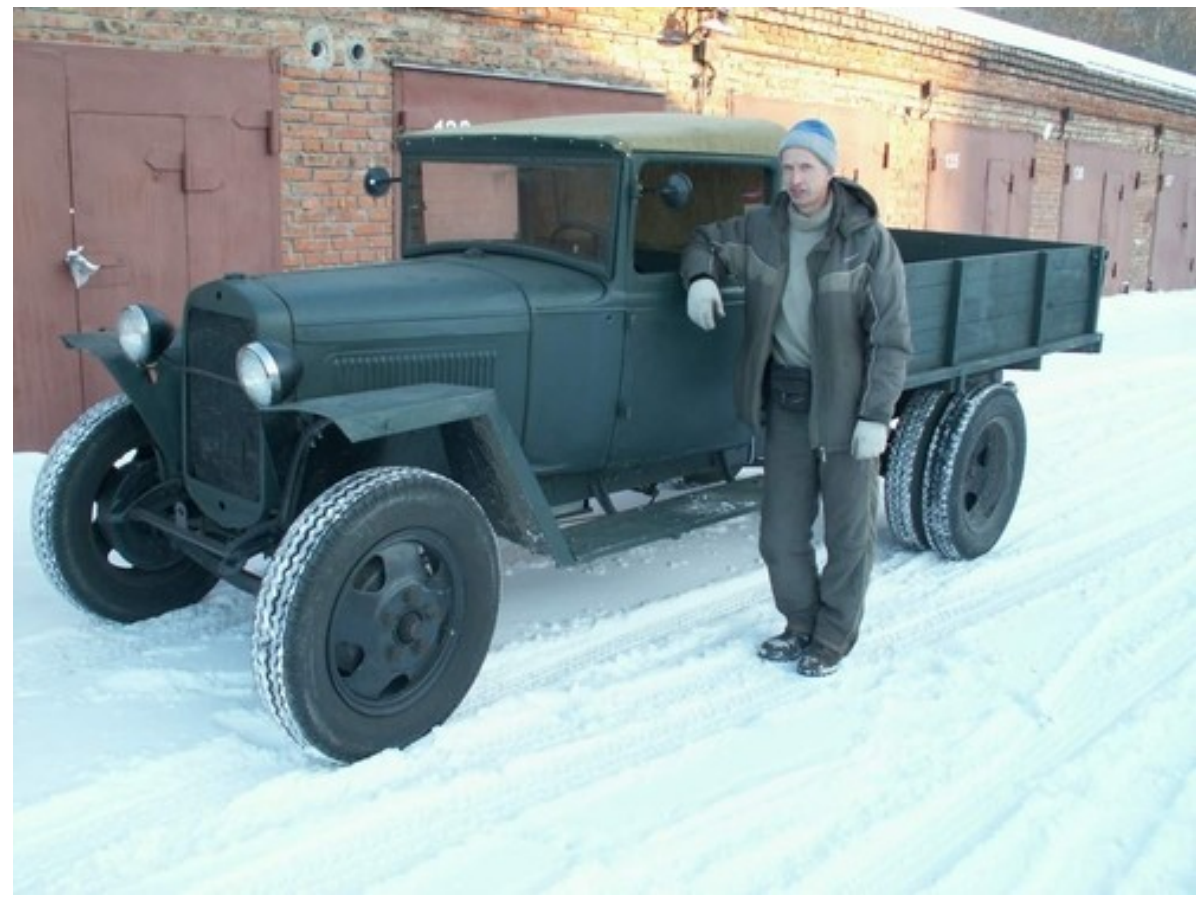

Puc. 1. А.А. Гайдамака и ГАЗ-ММ.

Следующим автомобилем, возрожденным этим любителем военно-транспортной техники, оказался грузовик ГАЗ-ММ, найденный в окрестностях Новосибирска. Модернизированная разновидность легендарной «полуторки» ГАЗ-АА, этот грузовик имел усиленные рулевое управление и подвеску, более мощный двигатель и новый карданный вал. Между тем внешних различий не наблюдалось. Угловатые крылья появились только на машинах военного и послевоенного выпуска. Во время войны производился ее упрощенный вариант ГАЗ-ММ-В ${ }^{4}$, на котором поршни изготавливались из березы, отсутствовали передние тормоза и имелся ряд других упрощений. В результате активной поисковой работы удалось приобрести части еще одной «полуторки» и значительное количество запасных частей, что

\footnotetext{
${ }^{4}$ Долматовский Ю.А. Автомобиль за 100 лет. М., 1986.
} 
позволило собрать не один, а два грузовика: базовый ГАЗ-ММ и бортовой ГАЗ-АА, переделанный в дальнейшем в ГАЗ-55 с кузовом автобусного типа, оборудованного для медицинских нужд. Автомобиль пережил в свое время все тяготы войны, был подарен руководством его водителю в качестве премии за героический труд. Аркадий отыскал его остатки в Омской области. Автобусный корпус отсутствовал. Его пришлось изготовить самостоятельно.

За этими памятниками нашей технической культуры вскоре появились и другие., в т.ч. инвалидная мотоколяска К-1В «Киевлянин» 1950 г. выпуска. Инвалидная мотоколяска Киевского мотоциклетного завода (КМ3) «Киевлянин», как упоминалось ранее, выпускалась в нашей стране с конца 1946 г. и бесплатно выдавалась инвалидам Великой Отечественной войны в качестве компенсации ограничения их физических возможностей. Среди населения она получила горько-ироническое прозвище «спасибо Гитлеру». Ирония относилась, вероятно, к советскому правительству вообе и к органам опеки в частности, не нашедшим возможности более достойного обеспечения своих граждан, которые пострадали на фронтах прошедшей войны. Действительно, этот довольно примитивный трицикл был создан специалистами КМЗ на базе производившегося тут же легкого мотоцикла «Киевлянин» К-1Б копии устаревшей немецкой машины Wanderer-1Sp довоенного образца. Он имел весьма скромные эксплуатационные характеристики и был небезопасен.

Все реставрационные работы проводятся Аркадием в его личном гараже при активной помощи двух сыновей. Начиная с 2005 г. Аркадий Гайдамака активно участвует в различных мероприятиях, проводимых в Новосибирске и Новосибирской области, а также за ее пределами. Первым мероприятием с его участием стала выставка старинной автомототехники в составе колонны общественной организации клуба «Ретротехника» 9 мая 2005 г. в центре Новосибирска, посвященная Дню Победы над фашистской Германией. В дальнейшем Гайдамака принимал участие в большинстве мероприятий этого клуба. В их числе: День города, ежегодная выставка «Автосиб», спортивные праздники, различные корпоративные и клубные мероприятия. Под эгидой историко-патриотического клуба «Сибирская гвардия» неоднократно участвовал в агитационных и иных пробегах по Новосибирской области и за ее пределами. Наиболее продолжительный пятидневный пробег «Гвардейское знамя» по маршруту Новосибирск - Томск - Кемерово - Барнаул - Новосибирск состоялся в 2012 г.

Особого внимания заслуживает взаимодействие с командой Международного ралли старинных автомобилей «Пекин - Париж», проходящего один раз в три года на территории России и нескольких других государств. Их первое знакомство состоялось в 2007 г., когда команда раллистов ненадолго остановилась в Новосибирске. В последующие годы, особенно после встречи Гайдамаки с директором ралли Филиппом Янгом, знакомство переросло в тесное сотрудничество, продолжавшееся все последующие годы. Совместно с коллегами из Бийска Аркадий осуществлял разработку маршрутов, техническую поддержку участников ралли от границы России на Чуйском тракте до Омска. Сам Аркадий не раз вместе с раллистами проделал путь от границ Новосибирской области до Урала. Взаимодействует Гайдамака и с российскими музеями. Так, K-1B экспонируется в Музее науки и техники СО РАН, а автобус «медичка» ГАЗ-55 - в одном из музеев в Кемерове 5 .

Одним из учредителей клуба «Ретротехника» является Николай Николаевич Бородин. Он начал увлекаться старинной автомототехникой в возрасте 28 лет, что ознаменовалось покупкой автомобиля «Москвич- 401». Приобретался он именно с целью восстановления его до оригинального состояния. Данный образец советского автопрома с момента своего выпуска на МЗМА в 1955 г. претерпел немало изменений, сделанных руками предыдущих владельцев. Детали и узлы от других автомобилей, неграмотные с технической точки зрения «улучшения» конструкции и, наконец, просто естественный износ автомобиля - вот далеко не полный перечень проблем, возникших перед реставратором.

\footnotetext{
${ }^{5}$ Тематическое интервью с А.А. Гайдамакой от 10.05.2020 г. Личный архив автора.
} 
Опыта подобной работы у Бородина не было. Пришлось изучать техническую и специальную литературу, осваивать приемы работы с механическими, электрическими и гидравлическими системами. Нужно заметить, что в 1970-е гг. в нашей стране практически не существовало специальных автомастерских, да и обычных пунктов автосервиса было чрезвычайно мало. Приходилось подолгу ожидать своей очереди. Качество выполняемых работ не соответствовало требуемому уровню, а автомобили, давно снятые с производства, и вовсе не обслуживались. Не существовало и практики изготовления на заказ тех или иных деталей. Единственная возможность проведения таких работ - поиск частных исполнителей, использующих в личных целях оборудование и материалы государственных предприятий, чему в значительной мере способствовали слабый контроль и низкая трудовая дисциплина.

Заводских запчастей также катастрофически не хватало. На всю Новосибирскую область существовал всего один небольшой магазин запасных частей. Приходилось искать их по объявлениям частных лиц в еженедельной газете «Реклама». Второй способ комплектования запасными частями - поездки на вещевые рынки, работавшие по воскресеньям в Новосибирске, Бердске, Искитиме и других населенных пунктах. В таких поисках приходилось посещать Бийск, Барнаул и даже Москву. Важным фактором, положительно повлиявшим на процесс восстановления «Москвича», явилось знакомство Бородина с устройством автомобилей. С раннего детства родной дед будущего реставратора - авиаконструктор В.А. Бородин приучал своего внука к технике. Уже к шести годам он научил его водить и обслуживать свой личный автомобиль М-20В «Победа». Все свое свободное время дед и внук проводили в гараже. В дальнейшем эти навыки весьма пригодились Николаю.

Подобный творческий путь - не редкость среди собирателей и хранителей старинных автомобилей и мотоциклов. Так, известный в Новосибирске реставратор и педагог Александр Дмитриевич Зверков также получил творческую «закваску» в раннем детстве. В данном случае в роли первого наставника, привившего Александру любовь к техническому творчеству, выступил руководитель лаборатории экспериментального транспорта Клуба юных техников СО АН СССР (КЮТ) Ларкин. Под руководством талантливого педагога Александр и приобщился к этому нелегкому, в прямом смысле, виду творчества.

Первой работой пятиклассника Зверкова стал легендарный автомобиль УАЗ-69А, на котором в свое время совершал поездки один из основателей и руководителей Сибирского отделения АН СССР академик М.А. Лаврентьев. Почувствовав вкус к возрождению из небытия памятников нашей технической культуры, Александр решил посвятить свою трудовую деятельность этой интересной работе. После окончания Новосибирского педагогического института, получив квалификацию общественного педагога, он стал штатным сотрудником системы дополнительного образования детей, поступив в 2000 г. на службу в качестве педагога дополнительного образования в Автомотоклуб Новосибирского городского Центра творчества детей и учащейся молодежи (бывший Дом пионеров). Теперь уже Зверков передавал свой опыт и знания молодому поколению, прививая своим воспитанникам интерес к ретротехнике. Первые работы Зверкова и его подопечных - автомобили ГАЗ-М1 и «Москвич-401». За ними последовали ГАЗ-67Б, немецкие автомобили военного периода: BMW-432, BMW-326 и др. Первые практики публичного представления восстановленной техники состоялись в мае-июне 2000 г. во время празднования Дня Победы и на выставке «Автосиб-2000». В дальнейшем участие этой техники в культурно-массовых мероприятиях Новосибирска и Новосибирской области стало традиционным ${ }^{6}$.

Преемником Ларкина стал молодой педагог Павел Евгеньевич Нестеренко. Окончив в 1997 г. Новосибирский государственный педагогический университет, он возглавил клубное формирование «Мототехника» Отдела технического образования Института гидродинамики им. М.А. Лаврентьева. Так официально теперь называется структура, более известная как КЮТ СО РАН. Формирование, или лаборатория, как такие подразделения КЮТ СО РАН назывались прежде, специализировалось на создании мотоциклов собственной конструкции, а также на тюнинге и доработке их современных серийных моделей.

\footnotetext{
${ }^{6}$ Тематическое интервью со А.Д. Зверковым от 23.03.2020 г. Личный архив автора.
} 


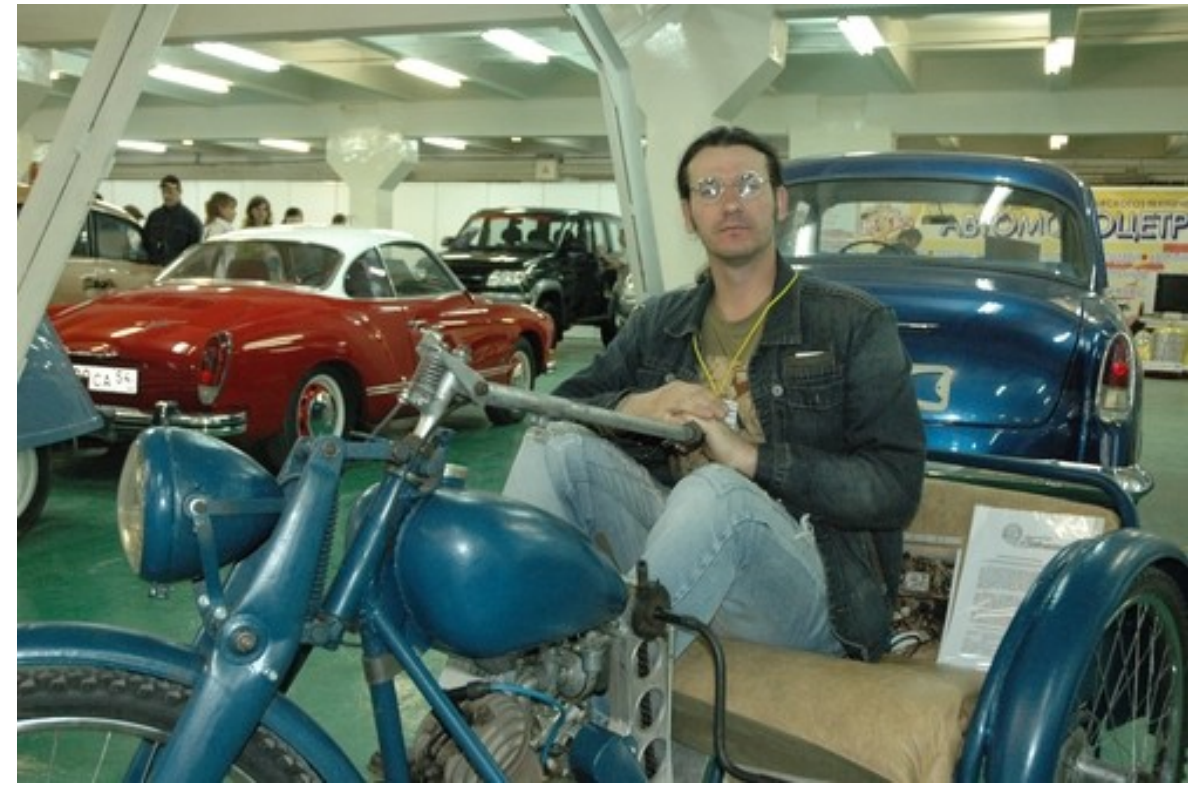

Рис. 2. А.Д. Зверков на «Автосиб-2007».

Первый опыт реставрации ретротехники КЮТовцы получили в 2010 г., участвуя в проекте «Автомобиль Лаврентьева». С него и началось увлечение Нестеренко старинной автомототехникой. В числе его работ - реплика немецкого мотоцикла BMW R-71. B начале 1940-х гг. этот армейский служака вермахта стал прототипом серии отечественных тяжелых мотоциклов с оппозитным двигателем - визитной карточкой мотоциклов BMW и, соответственно, советских машин М-72, K-750, «Урал», «Днепр» и других. В числе прочих работ Нестеренко и его воспитанников можно назвать немецкие BMW R-35, NSU-211, американский Harley-Davidson 1944 г. выпуска, ряд послевоенных машин.

Фирменным мероприятием КЮТ СО РАН с давних пор считается празднование Дня Победы. Как правило, это выражалось в устройстве совместно с Музеем науки и техники СО РАН и другими организациями интерактивной выставки автомототехники времен Великой Отечественной войны. Впервые это произошло в 2010 г. и продолжается поныне. Тогда экспозиция лаборатории Нестеренко представила вниманию зрителей мотоцикл М-72, мотоколяску К-1B и еще несколько экспонатов. При содействии Музея науки и техники $\mathrm{CO} \mathrm{PAH}^{7}$ была организована ансамблевая реконструкция обобщенного образа командного пункта мобильного дивизиона связи советских вооруженных сил начала - середины 1940-х гг. Посетителям предоставлялась возможность не только визуально познакомиться с техникой победы, но и испытать ее в действии. Выставки последующих лет имели сходный характер ${ }^{8}$.

Ряд экспонатов на подобных мероприятиях не раз представлял коллекционер из Академгородка Андрей Рябов. Андрей Викторович Рябов, окончив геологический факультет НГУ и юридический факультет Томского университета, ретро увлекся сравнительно недавно. Первая отреставрированная им машина появилась на «Автосибе» в 2002 г. Ею стал мотоцикл М-72. Данная работа была отмечена дипломом клуба «Ретротехника» в номинации «За лучшее соответствие оригиналу» ${ }^{9}$. За ним последовали другие мотоциклы. Всего в коллекции Рябова насчитывается около десятка старинных автомобилей и мотоциклов. Участие в «Автосибе» - далеко не единственный случай в творческой биографии Рябова. На его счету участие в различных мероприятиях, проводимых муниципальными и областными властями, общественными и государственными структурами. В их числе: Бердский

\footnotetext{
${ }^{7}$ О деятельности Музея науки и техники СО РАН см.: Запорожченко Г.М., Покровский Н.Н. Музей науки и техники Сибирского отделения РАН в социальном пространстве новосибирского Академгородка // Гуманитарные науки в Сибири. 2019. № 1. С. 105-110.

${ }^{8}$ Тематическое интервью с П.Е. Нестеренко от 20.01.2020 г. Личный архив автора.

${ }^{9}$ Текущий архив клуба «Ретротехника».
} 
региональный смотр-конкурс старинных и редких автомобилей и мотоциклов «Ретро Бердск-2012», пробег автомобилей и мотоциклов времен Великой Отечественной войны «Звездный рейд». Как член клуба реконструкторов в порядке клубной работы он предоставлял свою технику для военно-исторических реконструкций, снялся в нескольких фильмах местных киностудий ${ }^{10}$.

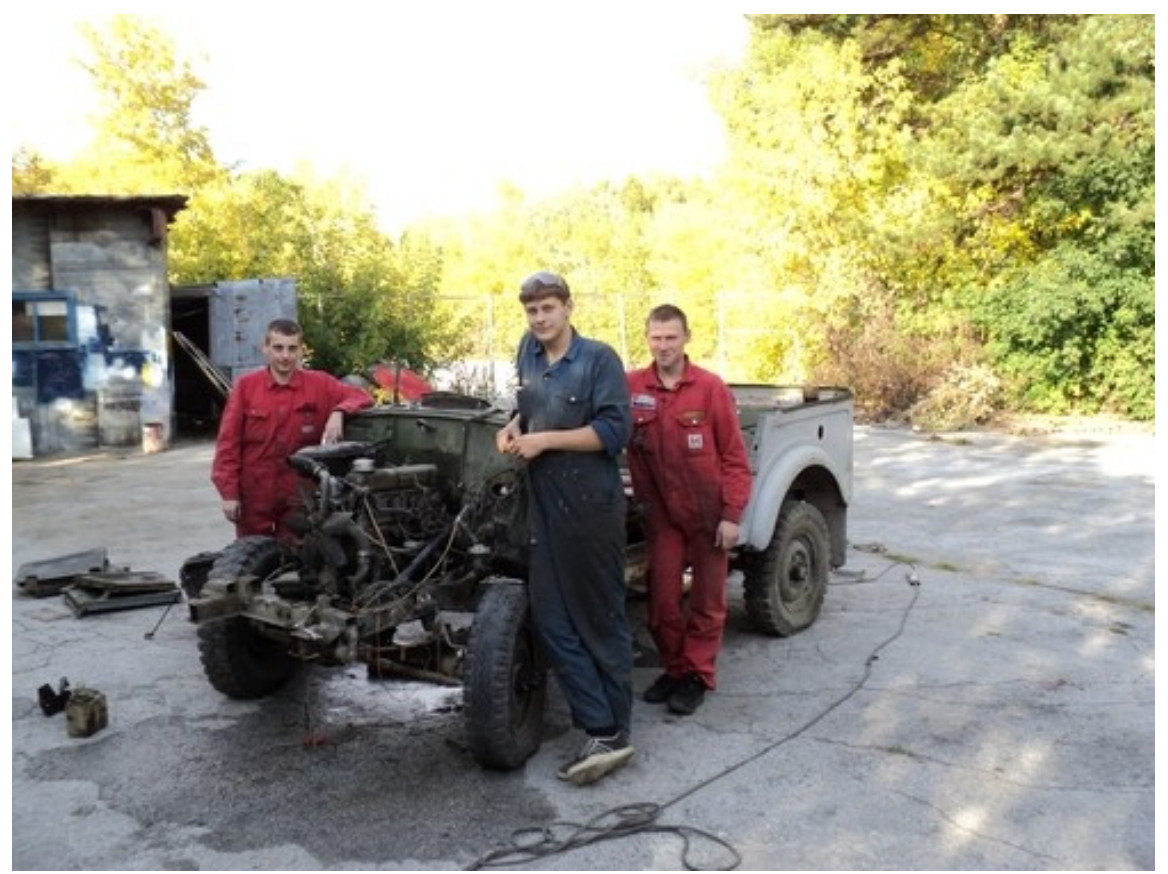

Рис. 3. П.Е. Нестеренко (слева) и его команда.

Достойны внимания коллекции транспортной техники, в т.ч. периода Великой Отечественной войны, некоторых новосибирских музеев. Наиболее крупная находится в Музее железнодорожной техники Западно-Сибирской железной дороги им. Н.А. Акулинина. Но ее описание, как и описание собраний других структур подобного рода, выходит за рамки данной работы.

В особую группу можно выделить реставраторов, занимающихся восстановлением старинной техники в коммерческих целях. В Новосибирске действует ряд подобных объединений, а также отдельных физических лиц, но их деятельность нельзя отнести к разряду любительских и в данной работе она подробно не рассматриваются. Лишь ко́ротко перечислим наиболее активных из них. В первую очередь следует назвать мастерскую «Ретро-54», основанную Андреем Лукницким. Андрей Вадимиович занимается реставрацией старинных автомобилей, а также сдает их в аренду, принимает заказы на обслуживание торжественных мероприятий и сам участвует в ретродвижении Новосибирска. Другим крупным специалистом в данной области является Владимир Курдюмов. Он не только реставрирует технику, но и занимается популяризацией научно-исторических знаний, участвует в культурнопросветительских мероприятиях, выпускает периодический авторетрожурнал «СпецАвтоСтрой» и планирует открыть музей старинной техники. Небольшие заказы берет группа упоминавшегося выше Нестеренко. Работы производятся безвозмездно в рамках занятий КЮТ.

Известна в Новосибирске и за его пределами частная фирма Романа Молчанова «Хаммербайк». Как и Курдюмов, Роман Молчанов не только восстанавливает технику, но и проводит общественно полезные мероприятия. Наиболее известное из них - байкерский фестиваль «Хаммерфест», организуемый Молчановым совместно с КЮТ СО РАН. На фестивале выставляется не только байкерская, но и старинная техника из Новосибирска, Новосибирской, Томской, Омской, Кемеровской областей и Алтайского края.

\footnotetext{
${ }^{10}$ Тематическое интервью с А.В. Рябовым от 04.05.2020 г. Личный архив автора.
} 


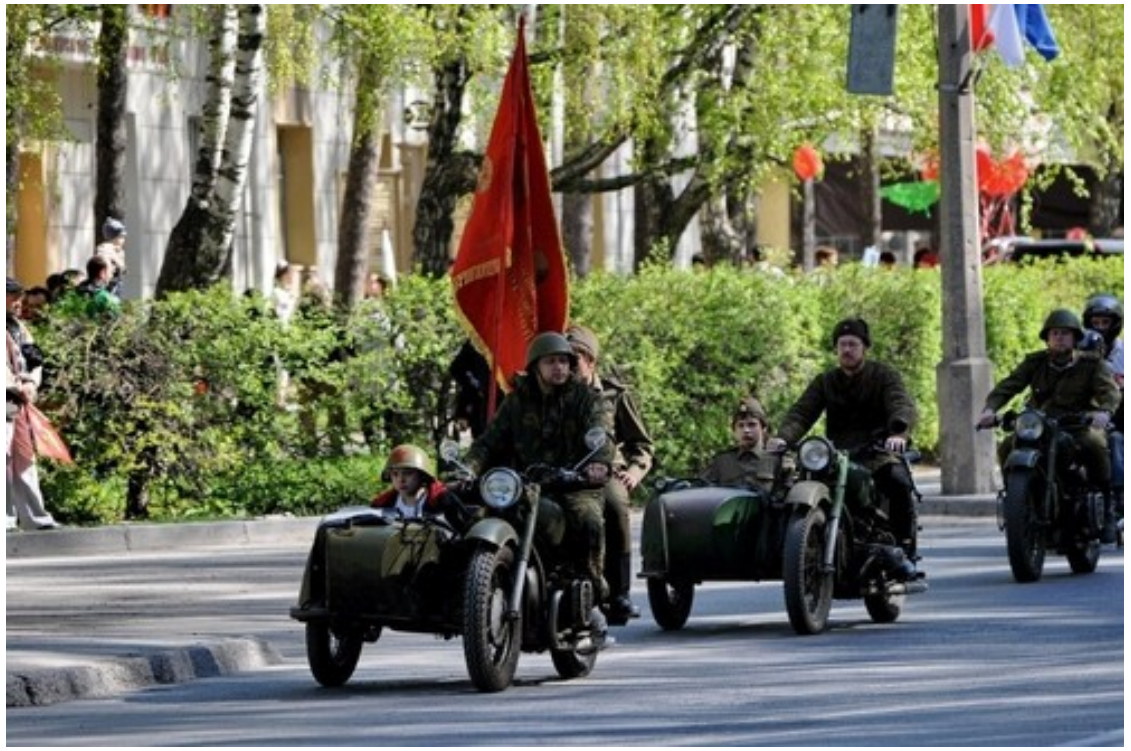

Рис. 4. «Хамммербайк» на марше.

Мы перечислили только некоторых любителей старинной техники. Кроме них в Новосибирске живет и работает большое количество других энтузиастов.

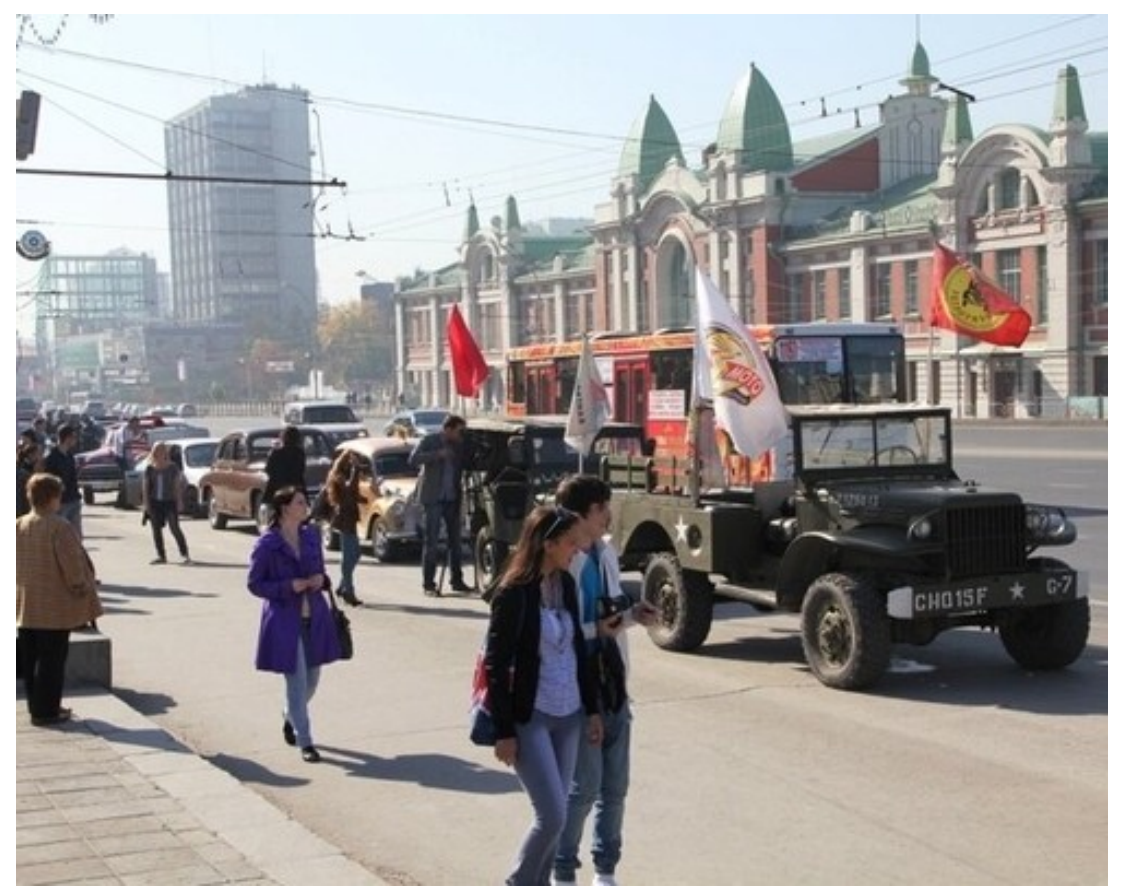

Рис. 5. Ретротехника на Красном проспекте г. Новосибирска.

Это, в первую очередь, зачинатель всего новосибирского ретродвижения, один из главных учредителей клуба «Ретротехника», организатор и руководитель Автомотоклуба при Дворце пионеров «Юниор», мастер спорта по картингу Николай Владимирович Строганцев; его бессменный помощник, секретарь и, на протяжении долгого времени, председатель клуба «Ретротехника», заслуженный педагог и известный краевед, автор многочисленных научно-популярных краеведческих работ Леонид Прокопьевич Чернобай; Владимир Николаевич Бочаров - учредитель газеты «Автолавка», участник и организатор многих мероприятий (в т.ч. в Москве - фестиваль старинных и необычных автомобилей «Автоэкзотика»). Хорошо известны коллекционеры Сваровский, Марченко, Манаенко, Борода, бывший следователь по особо важным делам Гладенко, Николай Косяченко, Марина Соколова; председатель клуба «Ретротехника» на протяжении десяти последних лет Елена Бакировна Антонова и ее супруг, педагог и реставратор Виктор Антонов, реконструкторы Жданов и Корбут, братья Киселевы, Борис Лихачев, Николай Никитенко, а также многие 
другие хранители овеществленной памяти нашей технической культуры. Все они достойны отдельного рассказа и в будущем мы постараемся осуществить подобную работу.

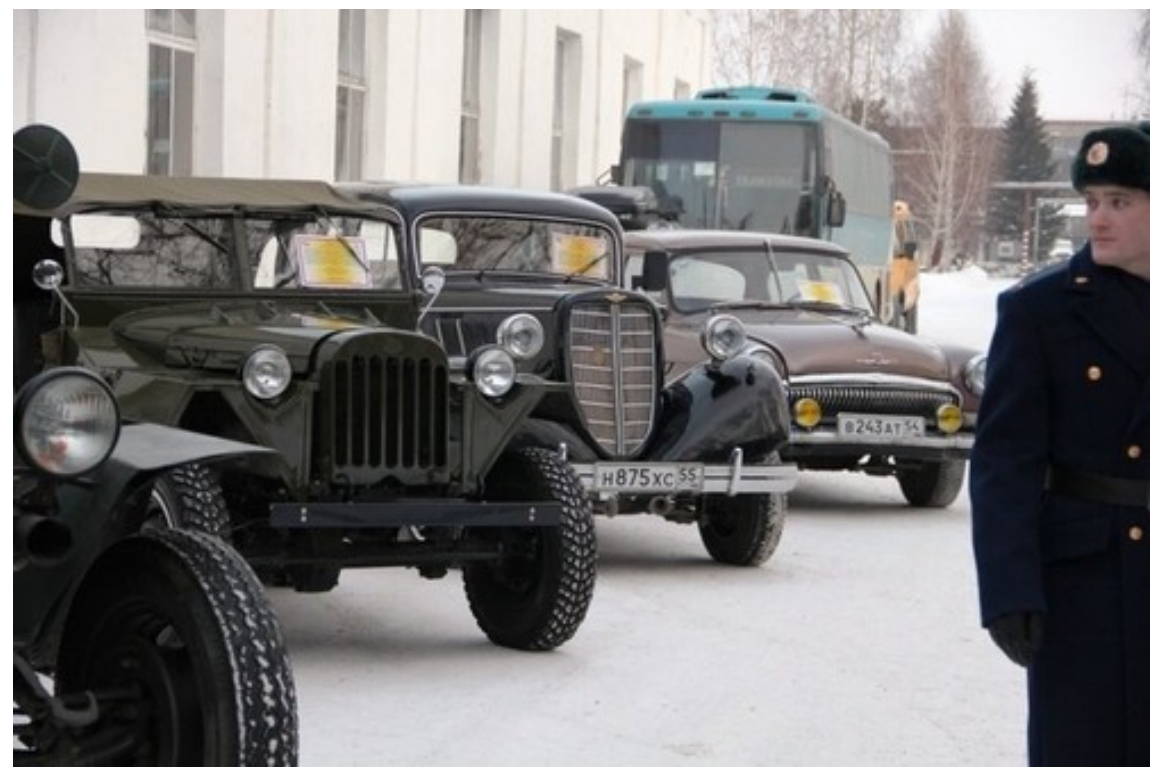

Рис. 6. Зимние гастроли клуба «Ретротехника».

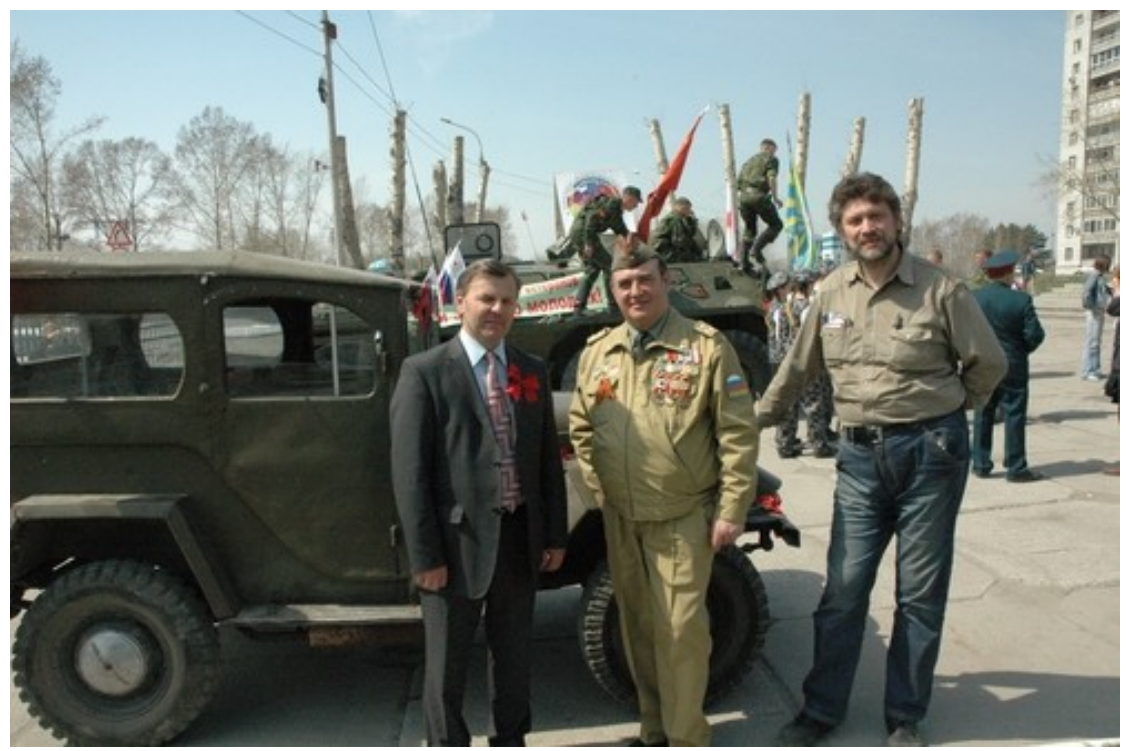

Рис. 7. Глава администрации Советского района г. Новосибирска, д-р филос. наук А.А. Гордиенко; председатель районной организации ветеранов Советского района г. Новосибирска, полковник в отставке

Е.Е.Лыбин; соучредитель клуба «Ретротехника» и руководитель Музея науки и техники СО РАН, канд. ист. наук Н.Н. Покровский на выставке военной техники в честь Дня Победы.

\section{Лumepamypa}

Вассерман Г.М., Куняев Н.А. Автомобиль ГАЗ-67Б. М.: Сельхозгиз, 1949. 189 с. Долматовский Ю.А. Автомобиль за 100 лет. М.: Знание, 1986. 16 с.

Запорожченко Г.М., Покровский Н.Н. Музей науки и техники Сибирского отделения РАН в социальном пространстве новосибирского Академгородка // Гуманитарные науки в Сибири. 2019. № 1. С. 105-110.

Технические характеристики автомобилей / под ред. А.Д. Абрамович. М.: Автотрансиздат, 1958. 152 с. 


\section{References}

Abramovich, A.D. (Ed.). (1958). Tehnicheskie kharakteristiki avtomobiley [Technical descriptions of cars]. Moscow, Avtotransizdat. 152 p.

Dolmatovskiy, Yu.A. (1986). Avtomobil za 100 let [Car for 100 years]. Moscow, Znanie. 161 p. Vasserman, G.M., Kunyaev N.A. (1949). Avtomobil GAZ-67B [Avtomobil GAZ-67B]. Moscow, Selkhozgiz. 189 p.

Zaporozhchenko, G.M., Pokrovskiy, N.N. (2019). Muzey nauki i tekhniki Sibirskogo otdeleniya RAN v soeuialnom prostranstve novosibirskogo Akademgorodka [Museum of science and technology of the Siberian branch of the Russian Academy of Sciences in the social space of Novosibirsk Akademgorodok]. In Gumanitarnye nauki v Sibiri. No. 16, pp. 105-110.

Статья поступила в редакцию 19.05.2020 г. 